\title{
Lipocyte hyperplasia and sexual maturation of Japanese quail (Coturnix coturnix japonica)
}

\author{
BY B. M. ORUWARI, J. A. CHERRY*, D. E. JONES AND W. L. BEANE \\ Poultry Science Department, Virginia Polytechnic Institute \& State University, \\ Blacksburg, Virginia 24061, USA
}

(Received 1April 1985-Accepted 12 December 1985)

\begin{abstract}
1. Hyperplastic growth of adipose tissue in Japanese quail (Coturnix coturnix japonica) was examined in relation to sexual maturity to determine whether fat cell number is fixed in mature individuals of this species.

2. Total DNA concentrations in the lipid (lipocyte) and non-lipid (stroma) fractions of collagenase (EC 3.4.24.3)-digested abdominal (retroperitoneal) fat depots were determined on a chronological-age basis from 28 to $240 \mathrm{~d}$ of age. The in vivo incorporation of [methyl ${ }^{3} \mathrm{H}$ ] thymidine into DNA of both the lipocyte and stroma fractions of abdominal fat from both ad lib. and restricted-fed (75\% of ad lib.) females was also examined at ages before and subsequent to sexual maturity.

3. In both males and females, significant increases in abdominal fat weights at ages beyond sexual maturity were associated with increased lipocyte DNA. Regardless of the feeding regimen and stage of maturity, substantial radioactivity was recovered from both the stromal and lipocyte fractions of abdominal fat when female quail were examined $24 \mathrm{~h}$ after the administration of tritiated thymidine. When examined $5 \mathrm{~d}$ post-injection, the majority of the radioactivity was contained in the lipid fraction of collagenase-digested adipose tissue.

4. Both the total DNA content of adipose tissue and the incorporation of tritiated thymidine into adipose tissue indicated that lipocyte hyperplasia contributes to postmaturational increases in fat deposition.
\end{abstract}

The concept, first proposed by Hirsch and his colleagues (Knittle \& Hirsch, 1968; Hirsch \& Han, 1969; Hirsch, 1976; Bulfer \& Allen, 1979), that postmaturational changes in the adipose tissue mass of mammals depend entirely on changes in cell size, has been challenged by several studies with rats (Lemonnier, 1972; Stiles et al. 1976; Faust et al. 1978; Bertrand et al. 1978, 1980, 1984; Klyde \& Hirsch, 1979a, b). The contribution of adipocyte hyperplasia to increased fat deposition in mature individuals of other species, however, has not been clarified. In the domestic chicken fed ad lib., for example, hyperplastic growth of adipose tissue has been thought to cease by 12-15 weeks of age (Pfaff \& Austic, 1976; Hood, 1982), which is before the age of sexual maturity. Although this age can be altered by nutrient restriction, evidence for hyperplastic modification of adipose tissue mass in the adult chicken, or in other avian species, is lacking (Pfaff \& Austic, 1976; March \& Hansen, 1977; Ballam \& March, 1978; March et al. 1982). A possible exception may be the recent report by March et al. (1984). Using histological techniques, they observed a bimodal distribution of fat cells, beginning at about 12 weeks of age, which appeared to represent two distinct adipocyte populations. The population composed of smaller adipocytes continued to increase up to 22 weeks of age, when the experiment was terminated. With their methodology, however, it was impossible to determine if the second population resulted from cellular multiplication or from the lipid filling of existing pre-adipocytes.

The objective of the present study was to examine hyperplastic growth of adipose tissue in Japanese quail (Coturnix coturnix japonica). Adipose tissue cellularity has not been examined in this species which, because of a conveniently short generation time, is becoming increasingly popular as a research animal. Evidence is presented that mature individuals of this species are capable of hyperplastic fat deposition. 


\section{MATERIALS AND METHODS}

Japanese quail were hatched and reared with sexes intermingled to $21 \mathrm{~d}$ of age in electrically heated battery brooders in a continuously illuminated room. The quail were fed either ad lib. or at $75 \%$ of ad lib. intake. Feed intake was monitored daily and the restricted feeding allotments were based on ad lib. intake the previous day.

At $21 \mathrm{~d}$ of age, the quail were separated by sex and wing-banded. Twenty females were then assigned to individual cages and monitored daily for the beginning of oviposition, while the remaining quail were caged in groups of three birds of the same sex. Beginning at this age, a daily photoperiod of $14 \mathrm{~h}$ light-10 h darkness was provided. Unless noted otherwise, the $a d$ lib. and restricted feeding treatments were continued throughout the study. The onset of sexual maturity was determined by first oviposition in females and the appearance of cloacal gland secretions in males (Sachs, 1969).

\section{Adipose tissue DNA}

At intervals of $7 \mathrm{~d}$, beginning at $28 \mathrm{~d}$ of age and continuing through $91 \mathrm{~d}$ of age, ten male and ten female quail fed ad lib. were randomly selected and weighed to the nearest $\mathrm{g}$. Blood from each female was collected into a heparinized syringe by anterior cardiac puncture for the subsequent determination of total plasma lipid (Folch et al. 1957) and plasma calcium (atomic absorption spectrophotometry). The quail were then killed by cervical dislocation and the abdominal (retroperitoneal) fat depot was removed for DNA determination. When ten of the twenty individually caged females had achieved first oviposition (52 d of age), they were examined in a similar manner to estimate adipose tissue DNA concentrations at sexual maturity. An additional ten females were examined at $240 \mathrm{~d}$ of age. Plasma lipid and $\mathrm{Ca}$ determinations were not obtained on the latter females.

Immediately after the quail were killed, the abdominal fat depot was removed, weighed to the nearest $\mathrm{mg}$, and rinsed with saline $(9 \mathrm{~g}$ sodium chloride/ $)$. All samples were subjected to collagenase (EC 3 4.23.3) digestion using Free's (1972) modification of the method originally described by Rodbell (1964), except that adipose tissue was not minced before digestion; preliminary observations indicated a more complete separation of the lipid (lipocyte) and non-lipid (stroma) fractions when the intact fat depot was digested. Incubation was accomplished in Krebs-Ringer phosphate-albumin buffer with collagenase (Sigma Chemical Company, St Louis, MO) concentrations varying from 3 to $5 \mathrm{mg} / \mathrm{ml}$ buffer depending on the activity of each specific lot. One $\mathrm{ml}$ of collagenase buffer was used per $\mathrm{g}$ of tissue.

After 60 min of digestion, the fibrous network of stromal tissue material was removed with forceps and the remaining suspension (lipocyte fraction) passed through a nylon mesh with $250-\mu 1$ openings. The lipocytes were then washed three times by suspending them in a fresh buffer, centrifuging for $1 \mathrm{~min}$ at $400 \mathrm{~g}$ in a tabletop centrifuge, and aspirating the infranatant buffer to the stromal fraction. The stromal fraction with buffer was then centrifuged, the buffer decanted, and the precipitate washed one final time. The term lipocyte was used to designate all buoyant (i.e. triacylglycerol-containing) adipose cells in the digested fraction regardless of size.

DNA concentrations in both the lipocyte and stromal fractions of abdominal fat were determined with a slight modification of the procedure described by Curtis-Prior et al. (1975). Instead of the recommended $1 \mathrm{ml}$ cell suspension, the entire volume of each fraction was extracted by proportionately adjusting the volume of the extraction solutions. Salmon-sperm DNA (Sigma Chemical Company) was used to prepare DNA standard solutions. Absorbance at $560 \mathrm{~nm}$ was determined using a Beckman Model 35 spectrophotometer. The results were expressed as total DNA in the stromal and lipocyte fractions of collagenase-digested abdominal fat. All values were analysed, within sex, by analysis of 
variance. When significant age differences occurred, the means were separated by the multiple range test of Duncan (1955).

\section{Thymidine incorporation}

The incorporation of $\left[\right.$ methyl- $\left.{ }^{3} \mathrm{H}\right]$ thymidine (ICN Chemical Company, Irvine, CA) into abdominal fat DN 4 of female quail was examined at several ages. The procedure, originally described by Hollenberg \& Vost (1968), consisted of the intramuscular injection of $25 \mu \mathrm{Ci}$ tritiated thymidine, followed $20 \mathrm{~min}$ later by an injection of $25 \mu \mathrm{mol}$ unlabelled thymidine (Sigma Chemical Company). The birds were subsequently killed and the abdominal fat was removed, weighed and subjected to collagenase digestion and DNA extraction using the procedures previously described. For counting of radioactivity, each fraction of DNAextracted adipose tissue was dried in a scintillation vial. To the dried sample, $15 \mathrm{ml}$ of a scintillation solution (Diotol) were added and each vial was subsequently counted using a Beckman liquid scintillation $\beta$-counter (Buhler, 1962). Radioactivity was corrected for background and the values were expressed as disintegrations $/ \mathrm{min}$.

Thymidine incorporation into adipose tissue DNA was examined at four different ages. In the initial experiment, ten females fed $a d l i b$. and ten subjected to restricted feeding were each, at $35 \mathrm{~d}$ of age, injected with tritiated thymidine. After $24 \mathrm{~h}$, five quail from both the ad lib. and restricted-fed groups were killed and radioactivity in both the stromal and lipocyte fractions of adipose tissue was determined. The remaining ten quail, five from each treatment group, were killed $5 \mathrm{~d}$ later and examined in a similar manner.

In the second experiment, which was conducted concurrently with the first, five additional females fed $a d l i b$, and ten females subjected to restricted feeding were injected with tritiated thymidine at $35 \mathrm{~d}$ of age. Five of the restricted-fed birds were then released to ad lib. feeding while the remaining ten were maintained on their previous feeding treatment. These fifteen quail were then killed when all five birds within each treatment group had reached lay. The ad lib., released and restricted-fed birds were killed 7, 21 and $28 \mathrm{~d}$ respectively after the administration of tritiated thymidine.

In Expt 3, mature and immature females of the same age were compared. At $56 \mathrm{~d}$ of age, ten mature quail fed $a d l i b$. and five immature restricted-fed quail were injected with tritiated thymidine. After $24 \mathrm{~h}$, five of the mature ad lib.-fed quail were killed. The remaining ten females were examined $5 \mathrm{~d}$ after the administration of tritiated thymidine; none of the restricted-fed quail entered lay before death.

In the final experiment (Expt 4), mitotic activity was examined at an age well past sexual maturity. At $84 \mathrm{~d}$ of age, ten quail fed $a d$ lib. and ten subjected to restricted feeding were treated with tritiated thymidine. Five of the restricted-fed quail were then released to ad lib. feeding to stimulate feed consumption and perhaps induce fat deposition. Five of the ad lib.-fed quail and the five remaining on the restricted feeding treatment were killed $24 \mathrm{~h}$ after tritiated thymidine administration. The remaining ten, five of which were fed ad lib. and five of which had been released to $a d$ lib. from restricted feeding, were examined $S \mathrm{~d}$ post injection.

All radioactivity values were analysed by analysis of variance. When appropriate, orthogonal comparisons (Steel \& Torrie, 1980) among means were made.

\section{RESULTS}

\section{Abdominal fat $D N A$}

Body-weight, abdominal fat weight, stroma weight and the DNA content of the stroma and lipocyte fractions of abdominal fat of male quail are presented in Table 1 . The development of the abdominal fat depot as the quail aged did not parallel changes in 
Table 1. Changes in body-weight, abdominal fat weight and DNA content of the lipid (lipocyte) and non-lipid (stroma) fractions of collagenase-digested abdominal fat of male Japanese quail (Coturnix coturnix japonica) from 28 to 91 d of age

(Mean values with their standard errors)

\begin{tabular}{|c|c|c|c|c|c|c|c|c|c|c|}
\hline \multirow{3}{*}{$\begin{array}{l}\text { Age } \\
\text { (d) }\end{array}$} & \multirow{2}{*}{\multicolumn{2}{|c|}{$\begin{array}{l}\text { Body-wt } \\
\text { (g) }\end{array}$}} & \multirow{2}{*}{\multicolumn{2}{|c|}{$\begin{array}{l}\text { Abdominal } \\
\text { fat wt }(\mathrm{g})\end{array}$}} & \multirow{2}{*}{\multicolumn{2}{|c|}{$\begin{array}{l}\text { Stroma wt } \\
(\mathrm{g})\end{array}$}} & \multicolumn{4}{|c|}{ Total DNA } \\
\hline & & & & & & & \multicolumn{2}{|c|}{ Stroma } & \multicolumn{2}{|c|}{ Lipocyte } \\
\hline & Mean & $\mathrm{SE}$ & Mean & SE & Mean & $\mathrm{SE}$ & Mean & SE & Mean & SE \\
\hline 28 & $115^{\mathrm{a}}$ & 3 & $0 \cdot 19^{a}$ & $0 \cdot 04$ & $0 \cdot 10^{\mathrm{a} b c}$ & 0.01 & $33^{\mathrm{a}}$ & 5 & $31^{\mathrm{a}}$ & 5 \\
\hline $\begin{array}{l}20 \\
35\end{array}$ & $134^{\mathrm{b}}$ & 3 & $0 \cdot 74^{\mathrm{ab}}$ & $0 \cdot 10$ & $0.08^{a}$ & 0.01 & $49^{b}$ & 6 & $95^{\mathrm{b}}$ & 9 \\
\hline 42 & $140^{\mathrm{bc}}$ & 2 & $1 \cdot 34^{\mathrm{b}}$ & $0 \cdot 15$ & $0.11^{b c d}$ & 0.01 & $52^{\mathrm{b}}$ & 4 & $100^{\mathrm{b}}$ & 8 \\
\hline 49 & $147^{b c d}$ & 2 & $1 \cdot 70^{\mathrm{b}}$ & 0.22 & $0 \cdot 08^{\mathrm{a}} \mathrm{b}$ & 0.01 & $42^{b}$ & 2 & $100^{b}$ & 10 \\
\hline 56 & $142^{\text {bed }}$ & 3 & $1 \cdot 44^{b}$ & 0.30 & $0 \cdot 14^{d}$ & $0 \cdot 01$ & $51^{b}$ & 6 & $106^{b}$ & 9 \\
\hline 63 & $142^{\mathrm{bcd}}$ & 2 & $1 \cdot 62^{b}$ & 0.17 & $0 \cdot 08^{a b}$ & 0.01 & $46^{b}$ & 3 & $117^{\mathrm{b}}$ & 8 \\
\hline 70 & $142^{\mathrm{bcd}}$ & 5 & $1.45^{\mathrm{b}}$ & 0.20 & $0 \cdot 07^{\mathrm{a}}$ & 0.01 & $32^{\mathrm{a}}$ & 5 & $122^{b}$ & 9 \\
\hline 77 & $153^{\mathrm{d}}$ & 3 & $3.67^{\mathrm{ed}}$ & 0.45 & $0 \cdot 12^{\mathrm{cd}}$ & 0.01 & $83^{e}$ & 6 & $253^{\mathrm{e}}$ & 29 \\
\hline 84 & $151^{\mathrm{d}}$ & 3 & $3 \cdot 14^{\mathrm{c}}$ & 0.41 & $0 \cdot 12^{\mathrm{cd}}$ & 0.01 & $60^{b}$ & 6 & $260^{\mathrm{e}}$ & 17 \\
\hline 91 & $153^{d}$ & 3 & $4 \cdot 41^{d}$ & 0.54 & $0 \cdot 13^{\mathrm{cd}}$ & 0.01 & $100^{\mathrm{c}}$ & 9 & $262^{c}$ & 21 \\
\hline
\end{tabular}

a, b, e, d Means in the same column having the same superscript letter were not significantly different $(P>0.05)$.

body-weight. No significant differences in body-weight occurred beyond $49 \mathrm{~d}$ of age, while a substantial increase in abdominal fat occurred in older quail. Significant increases in the DNA content of both the lipocyte and stromal fractions of adipose tissue accompanied the increased accumulation of abdominal fat at older ages. Lipocyte DNA increased from 28 to $35 \mathrm{~d}$ of age, remained fairly constant from 35 to $70 \mathrm{~d}$ of age, and again increased between 70 and $77 \mathrm{~d}$ of age. Although non-lipid (stroma) DNA concentrations were fairly constant over the ages examined, values at 77 and $91 \mathrm{~d}$ of age were significantly higher than the values at younger ages. Stroma weight also tended to increase at older ages, but the differences were less pronounced in comparison with stroma DNA values.

Except for an unusually high value at $84 \mathrm{~d}$ of age (Table 2), growth of the females was typical for Japanese quail. Both plasma $\mathrm{Ca}$ and total plasma lipids, which peak before the onset of lay in birds (McIndoe, 1969), increased dramatically by $42 \mathrm{~d}$ of age. Plasma $\mathrm{Ca}$ tended to remain elevated to $91 \mathrm{~d}$ of age while plasma lipid values fluctuated somewhat subsequent to sexual maturity.

Abdominal fat appeared to accumulate rapidly up to $49 \mathrm{~d}$ of age. Abdominal fat weights at 52 (median age at sexual maturity) and at $56 \mathrm{~d}$ of age, however, were substantially but not significantly smaller than those at $49 \mathrm{~d}$ of age. Subsequent to sexual maturity, abdominal fat weights tended to be rather constant to $77 \mathrm{~d}$ of age, after which a significant increase occurred. At $240 \mathrm{~d}$ of age, the quail had less fat than those examined at 84 or $91 \mathrm{~d}$ of age, with the differences being significant between the 84- and 240-d-old birds.

Increases, but not decreases, in abdominal fat weights were related to lipocyte DNA concentrations. Lipocyte DNA increased rapidly at early ages and tended to remain constant from 42 to $70 \mathrm{~d}$ of age. No significant differences were observed between 42 and $70 \mathrm{~d}$ of age. At 77, 84, 91 and $240 \mathrm{~d}$ of age, however, lipocyte DNA concentrations were significantly higher than those at earlier ages.

\section{Tritiated thymidine incorporation}

Thymidine incorporation into adipose tissue DNA was initially examined in sexually immature 35-d-old females (Table 3, Expt 1). At $1 \mathrm{~d}$ after the administration of tritiated 


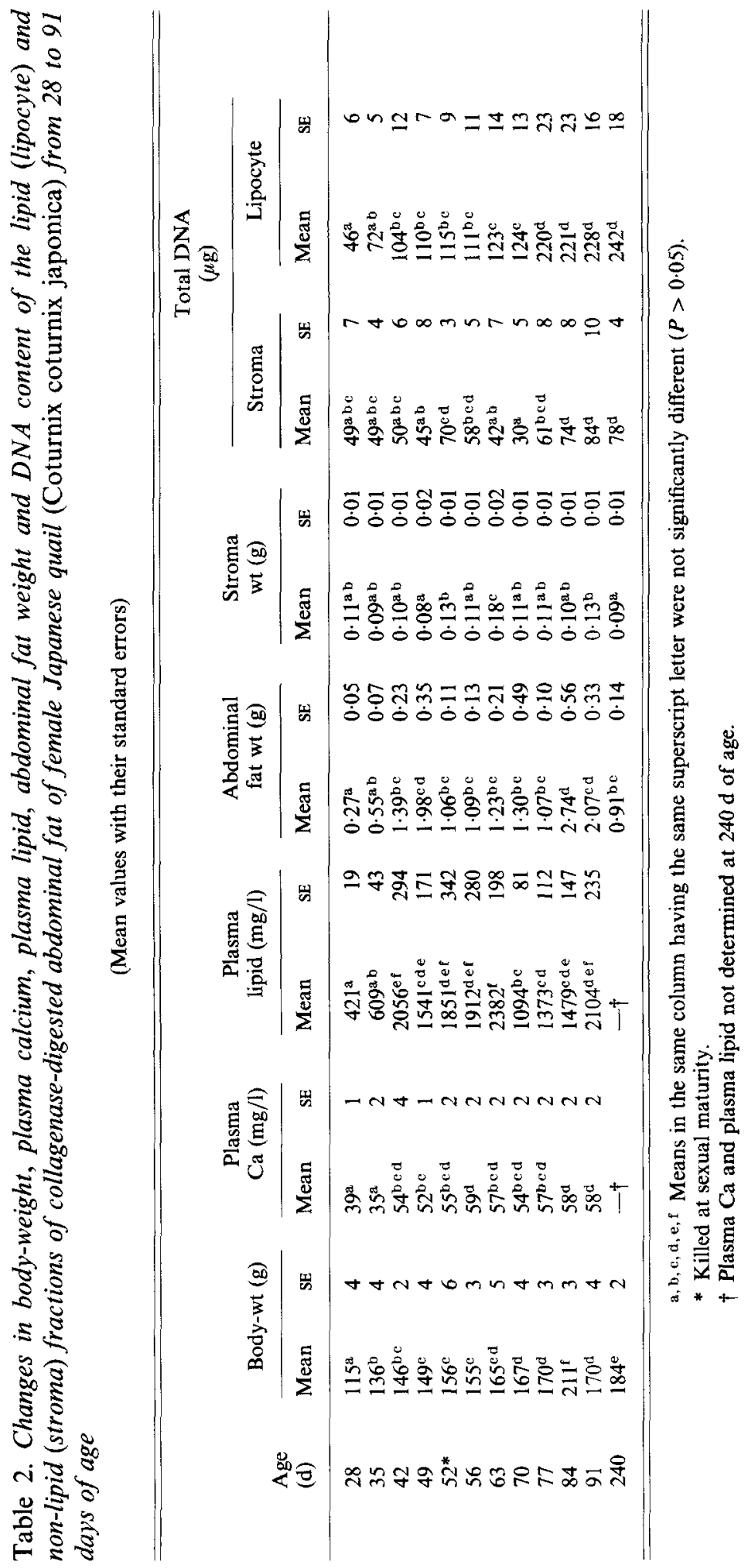




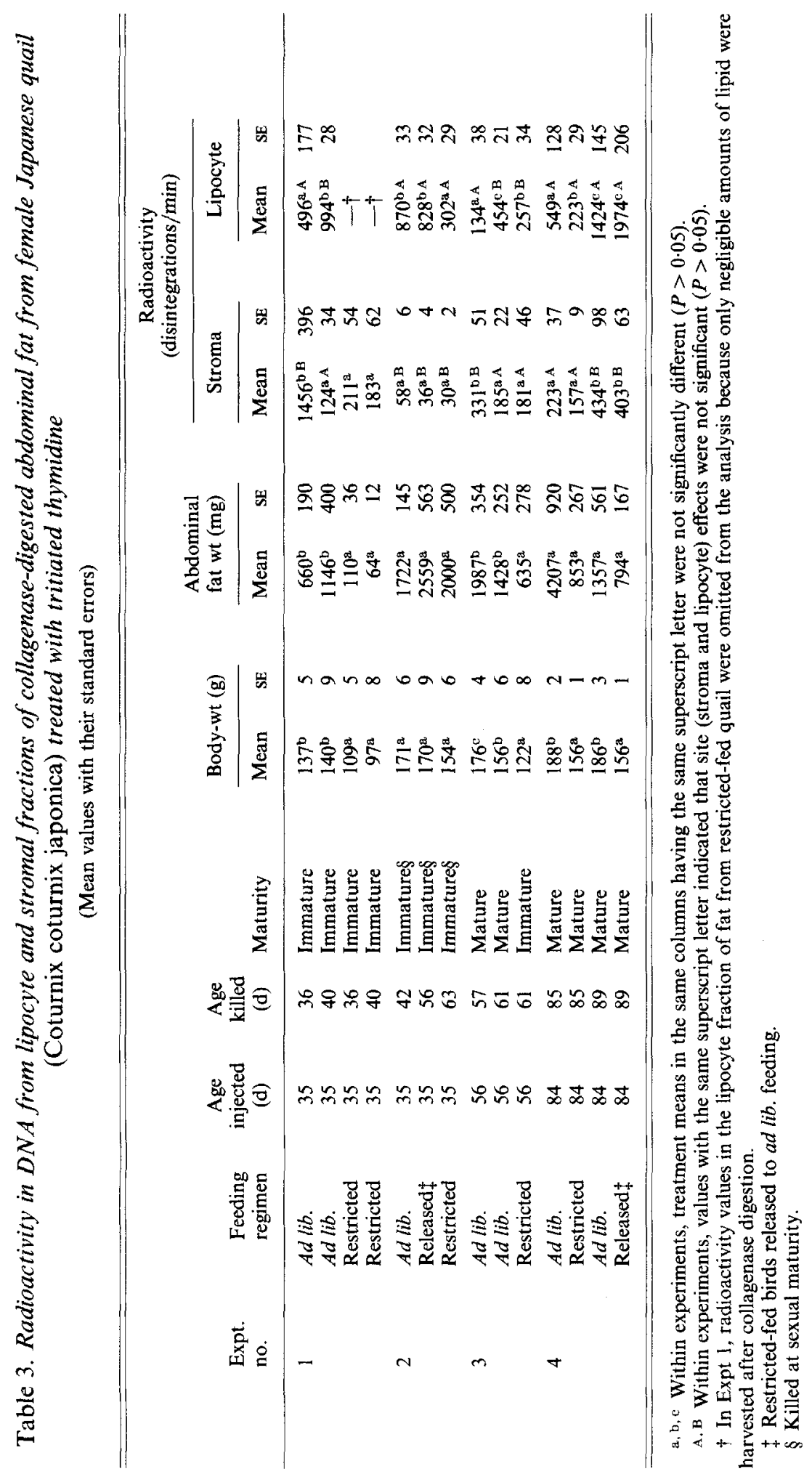


thymidine to quail fed ad lib., substantial radioactivity was found in both stromal and lipoctyte DNA; background radioactivity was about 20-30 counts/min. At day 1 post injection, significantly more radioactivity was located in the stromal than in the lipocyte fraction. At day 5 post injection, however, significantly more radioactivity was found in lipocyte DNA than in stromal DNA.

Abdominal fat deposition in the restricted-fed quail at $35 \mathrm{~d}$ of age was limited in comparison with those fed ad lib. At both days 1 and 5 post injection, measurable radioactivity was found in stromal but not in lipocyte DNA from the resricted-fed quail.

In Expt 2, tritiated thymidine was administered to quail at $35 \mathrm{~d}$ of age and radioactivity in adipose tissue was measured when egg production commenced. The quail fed ad lib. achieved lay $7 \mathrm{~d}$ after thymidine administration while those subjected to restricted feeding required an additional $28 \mathrm{~d}$ to begin egg production. The quail changed from restricted to ad lib. feeding when $35 \mathrm{~d}$ of age and began to lay 21 d later. Regardless of the feeding regimen, radioactivity in stromal DNA was only slightly above background levels while substantial radioactivity was found in lipocyte DNA. Significantly less radioactivity was found in lipocyte DNA of the restricted-fed quail in comparison with those subjected to the other feeding treatments.

In the third experiment utilizing radioactive thymidine, mature and immature females, all $56 \mathrm{~d}$ of age when injected, were compared. At $24 \mathrm{~h}$ after thymidine administration to mature females fed ad lib., the majority of the radioactivity recovered from adipose tissue was located in the stromal fraction. At day 5 post injection, the majority of the radioactivity was located in the lipocyte fraction. Moreover, at day 5 post injection, significantly more radioactivity was found in lipocyte DNA from the mature, ad lib-fed quail than from the immature quail which were restricted in feed intake.

In the final experiment, tritiated thymidine was administered to quail, all of which were mature, at $84 \mathrm{~d}$ of age. Regardless of the feeding treatment, the quail examined $1 \mathrm{~d}$ after thymidine injection had slightly but not significantly more radioactivity in lipocyte than in stromal DNA. At day 5 post injection, a substantial accumulation of radioactivity in lipocyte DNA was observed for both ad lib.-fed quail and for quail released to ad lib. from restricted feeding.

\section{DISCUSSION}

Assuming that increases in the size of a fat depot accompanied by increases in the total DNA content of that depot is indicative of mitotic activity, the results obtained with males indicated that new adipocytes were synthesized for lipid storage after the quail reached sexual maturity. Significant increases in abdominal fat weights observed beyond $70 \mathrm{~d}$ of age were accompanied by significant increases in the total DNA content of abdominal fat (Table 1). At 70 day of age the bird is well beyond the normal age at sexual maturity of male Japanese quail (Zelenka et al. 1984) and all quail fed ad lib. exhibited cloacal gland secretions by this age.

Although the DNA content of non-lipid components of abdominal fat was fairly constant over the ages examined, significant increases did occur in older birds. These increases may have represented the synthesis of new fat cells or pre-adipocytes, or may have been simply the result of increases in supporting connective tissue cells. Nonetheless, the substantial contribution of non-adipose cells to the total DNA content of a fat sample was apparent (Rodbell, 1964; Cleary et al. 1977). At $28 \mathrm{~d}$ of age, stromal DNA was essentially equal to lipocyte DNA. At older ages stromal DNA was $20-50 \%$ of that found in the lipocyte fraction. Similar results were obtained with females (Table 2).

Based on plasma $\mathrm{Ca}$ and plasma lipid values (Table 2), the neuroendocrine stimulation of sexual maturity in females was begun before $42 \mathrm{~d}$ of age. Egg production commenced about $10 \mathrm{~d}$ later. If a cessation in adipocyte hyperplasia is associated with the neuroendocrine 


\section{B. M. Oruwari, J. A. Cherry, D. E. Jones and W. L. Beane}

stimulation of maturity (Bulfer \& Allen, 1979), lipocyte DNA would be expected to peak during this period. This clearly did not occur. The accumulation of abdominal fat up to sexual maturity tended to be associated with increased concentrations of lipocyte DNA, although fat deposition at these stages was probably hypertrophic as well as hyperplastic in nature (Pfaff \& Austic, 1976; Hood, 1982). Abdominal fat weights at $52 \mathrm{~d}$ of age (median age at sexual maturity) and at $56 \mathrm{~d}$ of age, however, were substantially but not significantly smaller than those at $49 \mathrm{~d}$ of age. This reduction, which was not associated with reduced lipocyte DNA, may have resulted from the mobilization of stored lipid for deposition in egg yolk. At $84 \mathrm{~d}$ of age, however, a significant increase in abdominal fat weights associated with a significant increase in lipocyte DNA was observed. The quail examined at $240 \mathrm{~d}$ of age had less fat than those at $84 \mathrm{~d}$ of age, but this decrease was not associated with reduced lipocyte DNA. Subsequent to sexual maturity, therefore, increases in abdominal fat were associated with adipocyte hyperplasia while decreases in stored fat appeared to be strictly hypotrophic in nature. This latter observation was consistent with evidence that differentiated adipocytes persist long after stored lipid is mobilized (Hausberger, 1965; Haugebak et al. 1974; March et al. 1982).

Although immature adipocytes, or pre-adipocytes, have not been completely characterized, adipose tissue apparently consists of two cell pools. Primordial adipose cells formed within connective or vascular tissue subsequently mature into adipocytes after differentiation and accumulation of lipid (Frolich et al. 1972). When labelled thymidine is administered, radioactivity appears initially in the stroma or non-lipid fraction of collagenase-digested adipose tissue; this radioactivity may represent the synthesis of primordial adipose cells or may simply reflect mitotic activity in connective or supporting tissues. Subsequently, however, radioactivity accumulates in the lipid fraction of adipose tissue, indicating that stored lipid is contained in newly-synthesized cells. A negligible accumulation of radioactivity in the lipocyte fraction, therefore, indicates an absence of adipocyte hyperplasia. This concept has been used by several laboratories to characterize hyperplastic growth of adipose tissue in rats (Hollenberg \& Vost, 1968; Frolich et al. 1972; Greenwood \& Hirsch, 1974; Bertrand et al. 1978; Klyde \& Hirsch, 1979a, b).

Overall, our results were consistent with studies in which thymidine incorporation into rat adipose tissue was examined. At $24 \mathrm{~h}$ after the administration of tritiated thymidine, more radioactivity was located in the stromal than in the lipocyte fraction of adipose tissue (Table 3). When examined several days post injection, the radioactivity was concentrated in the lipocyte fraction. This apparent flux of radioactivity from stromal to lipocyte DNA may indicate that quail resemble other species in that adipogenesis involves initial mitotic activity of progenitor cells located in non-lipid fractions of adipose tissue, followed by the maturation of these progenitor cells into mature adipocytes (Simon, 1965). From similar findings, however, Klyde \& Hirsch $(1979 a, b)$ concluded that adipocyte progenitors reside in both the stroma and lipocyte fractions. Our results do not contradict either concept.

Hollenberg \& Vost (1968) observed that $2 \mathrm{~d}$ were required for substantial radioactivity to appear in lipocyte DNA after rats were treated with radioactive thymidine. In our experiments, radioactivity was consistently recovered from the lipocyte fraction $24 \mathrm{~h}$ after thymidine administration. This observation could reflect contamination of the fat-cell fractions with stromal cells; it would be necessary to use autoradiographic techniques to demonstrate conclusively that the radioactivity was located specifically in fat cells. Histological examination, however, failed to reveal the presence of stromal tissue in the lipocyte fraction. The early appearance of radioactivity in lipocyte DNA therefore might indicate that maturation of adipose cells from stromal elements proceeds more rapidly in the quail than in the rat. In retrospect, it would have been enlightening to examine these fractions at times less than $24 \mathrm{~h}$ post injection. 
The principal objective of the present study was to examine lipocyte hyperplasia at different stages of maturation. In the initial experiment using tritiated thymidine, immature quail were examined at $35 \mathrm{~d}$ of age. Under ad lib. feeding, the accumulation of radioactivity in lipocyte DNA indicated clearly that quail at this age were capable of hyperplastic growth of adipose tissue (Table 3, Expt 1). These results were anticipated based on previous findings obtained with rats (Hollenberg \& Vost, 1968). Under restricted feeding, only negligible radioactivity was harvested from the lipocyte fraction of abdominal fat. This failure to detect substantial radioactivity was probably attributable to reduced fat deposition rather than the absence of the capability of lipocyte hyperplasia. In the second experiment, in which quail were treated with thymidine at $35 \mathrm{~d}$ of age and examined at the beginning of lay, radioactivity was found in lipocyte DNA of restricted-fed quail.

When a direct comparison of mature and immature females was made in Expt 3, there was no evidence that lipocyte hyperplasia had ceased at sexual maturity. At day 5 post injection, significantly more radioactivity was found in lipocyte DNA from the mature, ad lib.-fed quail than in lipocyte DNA from the immature, restricted-fed quail. If lipocyte hyperplasia ceased before sexual maturity, opposite trends would have been expected. Finally, when thymidine was administered to mature quail of $84 \mathrm{~d}$ of age (Expt 4), there was again no evidence that hyperplasia had ceased. When fat deposition was stimulated by releasing restricted-fed quail to ad lib. feeding, substantial radioactivity accumulated in lipocyte DNA.

In conclusion, both the total DNA content of adipose tissue and the incorporation of tritiated thymidine into abdominal fat DNA indicated that mature Japanese quail exhibit hyperplastic fat deposition. Quail of both sexes exhibited hyperplastic increases in abdominal fat deposition subsequent to $70 \mathrm{~d}$ of age. It was not known if such increases in fat deposition are typical for Japanese quail or whether an environmental influence was involved. Because Japanese quail is a migratory species, vernal fat deposition may have been involved (Yokoyama, 1977). The results, therefore, may or may not be applicable to non-migratory avian species.

This study was supported by a National Institute of Health grant RO1 AGO 4197-01.

\section{REFERENCES}

Ballam, G. C. \& March, B. E. (1978). Poultry Science 58, 940-948.

Bertrand, H. A., Masoro, E. J. \& Yu, B. P. (1978). Science 201, 1234-1235.

Bertrand, H. A., Masoro, E. J. \& Yu, B. P. (1980). Journal of Gerontology 35, 927-939.

Bertrand, H. A., Stacy, C., Masoro, E. J., Yu, B. P., Murato, I. \& Maeda, H. (1984). Journal of Nutrition 114, $127-131$.

Buhler, D. R. (1962). Analytical Biochemistry 4, 413-417.

Bulfer, J. M. \& Allen, C. E. (1979). Bioscience 29, 736-741.

Cleary, M. P., Brasel, J. A. \& Greenwood, M. R. C. (1977). American Journal of Physiology 236, 508-513.

Curtis-Prior, P. B., Hanley, T. \& Temple, N. J. (1975). Analyst 100, 105-110.

Duncan, D. B. (1955). Biometrics 11, 1-7.

Faust, I. M., Johnson, P. R., Stern, J. S. \& Hirsch, J. (1978). American Journal of Physiology 235, 279-286.

Folch, J., Lees, M. \& Sloane-Stanley, G. H. (1957). Journal of Biological Chemistry 226, 497-509.

Free, C. A. (1972). In Methods of Molecular Biology, vol. 3, pp.223-228 [M. Chasing, editor]. New York: Marce] Dekker.

Frolich, J., Vost, A. \& Hollenberg, C. H. (1972). Biochemistry Biophysics Acta 280, 579-587.

Greenwood, M. R. C. \& Hirsch, J. (1974). Journal of Lipid Research 15, 474-483.

Haugebak, C. D., Hedrick, H. G. \& Asplund, J. M. (1974). Journal of Animal Science 39, 1016-1025.

Hausberger, F. X. (1965). In Handbook of Physiology, pp. 519-528 [A. E. Ronald and G. F. Cahill Jr, editors]. Baltimore: Williams and Wilkins Company.

Hirsch, J. (1976). New England Journal of Medicine 295, 389-390.

Hirsch, J. \& Han, P. W. (1969). Journal of Lipid Research 10, 77-82.

Hollenberg, C. H. \& Vost, A. (1968). Journal of Clinical Investigation 47, 2485-2498. 


\section{B. M. Oruwari, J. A. Cherry, D. E. Jones and W. L. Beane}

Hood, R. L. (1982). Poultry Science 61, 117-121.

Klyde, B. J. \& Hirsch, J. (1979a). Journal of Lipid Research 20, 691-704.

Klyde, B. J. \& Hirsch, J. (1979 b). Journal of Lipid Research 20, 705-715.

Knittle, J. L. \& Hirsch, J. (1968). Journal of Clinical Investigation 47, 2091-2098.

Lemonnier, D. (1972). Journal of Clinical Investigation 51, 2907-2915.

McIndoe, W. M. (1969). Biochemical Journal 72, 153-158.

March, B. E., Chu, S. \& MacMillan, C. (1982). Poultry Science 61, 1137-1146.

March, B. E. \& Hansen, G. (1977). Poultry Science 56, 886-894.

March, B. E., MacMillan, C. \& Chu, S. (1984). Poultry Science 63, 2207-2216.

Pfaff, F. E. Jr \& Austic, R. E. (1976). Journal of Nutrition 106, 443-450.

Rodbell, M. (1964). Journal of Biological Chemistry 239, 753-755.

Sachs, B. O. (1969). Hormones and Behavior 1, 7-24.

Simon, G. (1965). In Handbook of Physiology, pp. 101-107 [A. E. Ronald and G. F. Cahill Jr, editors]. Baltimore: Williams and Wilkins Company.

Steele, R. G. B. \& Torrie, J. H. (1980). Principles and Procedures of Statistics: a Biomedical Approach, 2nd ed. New York: McGraw Hill Book Company.

Stiles, J. W., Francendese, A. \& Masoro, E. J. (1976). American Journal of Physiology 229, 1561-1568.

Yokoyama, K. (1977). Cell Tissue Research 176, 91-108.

Zelenka, D. J., Cherry, J. A., Nir, I. \& Siegel, P. B. (1984). Growth 48, 16-28. 